\title{
Aggregation of Human Eyelid Adipose-derived Stem Cells by Human Body Fluids
}

\author{
Yeonhwa Song, Sujin Yun, Hye Jin Yang, A Young Yoon and Haekwon Kim ${ }^{\dagger}$ \\ Dept. of Biotechnology, Seoul Women's University, Seoul 139-774, Korea
}

\begin{abstract}
Fetal bovine serum (FBS) is the most frequently used serum for the cultivation of mammalian cells. However, since animal-derived materials might not be appropriate due to safety issues, allogeneic human serum (HS) has been used to replace FBS, particularly for the culture of human cells. While there has been a debate about the advantages of HS, its precise effect on human adult stem cells have not been clarified. The present study aimed to investigate the effect of HS on the human eyelid adipose stem cells (HEACs) in vitro. When HEACs were cultivated in a medium containing $10 \%$ HS, many cells moved into several spots and aggregated there. The phenomenon was observed as early as 9 days following $10 \%$ HS treatment, and 12 days following 5\% HS plus 5\% FBS treatment. However, the aggregation was never observed when the same cells were cultivated with $10 \%$ FBS or bovine serum albumin. To examine whether cell density might affect the aggregation, cells were seeded with different densities on 12-well dish. Until the beginning of aggregation, cells seeded at low densities exhibited the longest culture period of 16 days whereas cells seeded at high densities showed the shortest period of 9 days to form aggregation. The number of cells was $15.1 \pm 0.2 \times 10^{4}$ as the least for the low density group, and $29.3 \pm 2.8 \times 10^{4}$ as the greatest for the high density group. When human cord blood serum or normal bovine serum was examined for the same effect on HEACs, interestingly, cord blood serum induced the aggregation of cells whereas bovine serum treatment has never induced. When cells were cultivated with $10 \%$ HS for 9 days, they were obtained and analyzed by RT-PCR. Compared to FBS-cultivated HEACs, HS-cultivated HEACs did not express VIM, and less expressed GATA4, PALLD. On the other hand, HS-cultivated HEACs expressed MAP2 more than FBS-cultivated HEACs. In conclusion, human adult stem cells could move and form aggregates by the treatment with human body fluids.
\end{abstract}

Key words : Aggregation, Human eyelid adipose-derived stem cells, Human allogeneic serum, Human body fluids

\section{INTRODUCTION}

Stem cells have been studied for replacing damaged cells or supporting regeneration of damaged tissue (Assmus et al., 2002; Wollert et al., 2004). Human embryonic stem cells (ESCs) have been evaluated as therapeutic cell sources due by their multi-lineage differentiation potential including neural cells (Reubinoff et al., 2000), blood cells (Kaufman et al., 2001) and pancreatic $\beta$ -cells (D'Amour et al., 2006). However, clinical use of ESCs is faced with the ethical issue and the risk

\footnotetext{
† Corresponding author: Haekwon Kim, Dept. of Biotechnology, Seoul Women's University, Seoul 139-774, Korea. Phone: +82-2970-5665, Fax: +82-2-974-2473, E-mail: hwkim@swu.ac.kr
}

of teratoma formation (Kroon et al., 2008). The other cell source is induced pluripotent stem cells (iPSCs). Lately human iPSCs was created (Yamanaka, 2009; Thomson, 2012) through enforced expression of a limited number of genes critical to maintenance of pluripotency in ESCs. Similar to ESCs, iPSCs have also demonstrated their abilities of self-renewal and differentiation potential to all three germ layers (Sullivan et al., 2010; Burridge et al., 2011). However, using the exogeneous expression of four genes, including two pluripotency transcription factors (Oct4 and Sox2) and two protooncogenes (c-Myc and Klf4) (Takahashi et al., 2007), could raise a high risk of tumorigenesis when transplanted in vivo (Moriguchi et al., 2010).

Adult stem cells do not accompany an ethical issue 
and there is no report of the teratoma formation after transplantation in vivo. Previously, mesenchymal stem cells (MSCs) have been shown to proliferate multiple times in vitro and to differentiate into a variety of cell types of mesodermal lineage (Prockop, 1997). Later studies have also shown their differentiation potential into endodermal lineage such as hepatocytes (Wei et al., 2008), pancreatic $\beta$-cells (Kang et al., 2009), and ectodermal lineage including neurons (Woodbury et al., 2000). MSCs reside in various tissues including bone marrow, adipose tissue, umbilical cord, and amniotic membrane (Pittenger et al., 1999, Minguell et al., 2001). Although bone marrow-derived stem cells (BM-MSCs) are the most well-known and characterized MSCs, their retrieval from bone marrow accompany a highly invasive procedure. Therefore, many studies have been looking for alternative sources. Human eyelid adiposederived stem cells (HEACs), which could be obtained during plastic surgery, were successfully isolated and have shown the characteristics of neural crest cells. Moreover, they exhibited the typical characteristics of MSC, as revealed by differentiation into mesodermal lineages including adipocyte, osteoblast and chondrocyte, and an endodermal lineage such as insulin-secreting cells (Kang et al., 2009). Thus HEACs appear to be useful as cells sources for cell therapeutics.

FBS-containing medium has been the conventional medium for the isolation and cultivation of MSCs (Horwitz et al., 1999). However, using animal derivatives might bring a risk of contamination with bacteriophage, infectious bovine rhinotracheitis, parainfluenza-3, bovine viral diarrhea virus (Erickson et al., 1991), bacteria, prions, nanobacteria, yeast and endotoxins. A single injection of $10^{8} \mathrm{hMSCs}$ grown under $20 \%$ FCS would carry with it approximately 7 to $30 \mathrm{mg}$ of calf serum proteins which might cause immune response to FBS in human patients when they were transplanted (Spees et al., 2004). Therefore, researchers are searching for alternative sources for human cell cultivation instead of FBS. Recent studies have suggested human body fluids including autologous serum (autoHS) (Yamamoto et al., 2003; Stute et al., 2004), allogeneic human serum (alloHS) (Le Blanc et al., 2007; Tateishi et al., 2008) umbilical cord blood serum (CBS) (Ma et al., 2012; Tekkatte et al., 2012) and platelet derivatives (Kocaoemer et al., 2007; Bieback et al., 2009), follicular fluid (HFF) (Qui et al., 2012) could be promising substitutes. Yet, there have been controversial issues about the advantages of HS, and detailed studies about the effects of human serum on stem cells have not been done.

For the first time, the present study revealed that human adult stem cells could move and form aggregates in vitro by the treatment with alloHS. Interestingly, the induction of the aggregation appears be specific to the human body fluids. And the change of expression of cytoskeleton-related genes is observed at HEACs cultivated with $10 \%$ HS.

\section{MATERIALS \& METHODS}

\section{Human allogeneic serum (HS)}

HS was obtained from whole-blood donations of 6 female Asian donors. Blood was drained into sterile 50 $\mathrm{ml}$ tube (SPL, Korea) without anticoagulants and allowed to clot overnight at $4{ }^{\circ} \mathrm{C}$. They were centrifuged at 3,000 rpm for $30 \mathrm{~min}$, and the supernatant was centrifuged again at $3,000 \mathrm{rpm}$ for $30 \mathrm{~min}$ to remove any remaining particles. The six allogeneic human sera were pooled and sterile-filtered through $0.2-\mu \mathrm{m}$ pores (Millipore, Billerica, MA). After inactivation at $56^{\circ} \mathrm{C}$ for $30 \mathrm{~min}$, HS was aliquoted into $15 \mathrm{ml}$ tube and stored at $-20^{\circ} \mathrm{C}$ until use.

\section{Isolation and culture of HEACs}

The human eyelid adipose tissue was obtained from five patients aged between 20 and 56 years (mean age, $39.6 \pm 5.9$ years) undergoing cosmetic surgery with in- 
formed consent. They were washed with Dulbecco's phosphate buffered saline (DPBS, Gibco, Grand Island, $\mathrm{MA}$ ) and treated with $0.075 \%$ type I collagenase (Gibco) in DPBS for $30 \mathrm{~min}$ at $37^{\circ} \mathrm{C}$ with gentle stirring. The supernatant was discarded and mixed with an equal volume of Dulbecco's modified Eagle's medium - low glucose (DMEM-LG, Gibco) supplemented with $10 \%$ FBS (Gibco) to neutralize the enzymatic activity. After centrifugation at $3,000 \mathrm{rpm}$ for $10 \mathrm{~min}$, the supernatant was removed and the remaining cell suspension was washed several times with DMEM-LG, and were plated in $25-\mathrm{cm}^{2}$ culture flask (Nunc, Rochester, NY) containing DMEM-LG supplemented with $100 \mathrm{U} / \mathrm{ml}$ penicillin (Gibco), 0,1 $\mathrm{mg} / \mathrm{ml}$ streptomycin (Gibco) $3.7 \mathrm{mg} / \mathrm{ml}$ sodium bicarbonate, and 10\% FBS. The medium was changed twice a week. Passage 4 HEACs were tested in this study.

\section{Aggregation assay}

HEACs were seeded in 12-well plate (Costar) at density of 1,000 cells $/ \mathrm{cm}^{2}$. Cells were cultivated with DMEM-LG containing $10 \%$ of HS, CBS, FBS, bovine serum (BS, Gibco), 15\% Human follicular fluid (HFF), $5 \%$ HS $-5 \%$ FBS and $0.4 \%$ of bovine serum albumin (BSA). Morphology of cells was observed during 18 days of culture. To investigate the timing and number of cells at the beginning chemotactical aggregation, cells were plated on a 12-well dish at a density of $10^{2}, 10^{3}, 10^{4}$ or $10^{5}$ cells/well. The number of cells was counted on the day of beginning of the aggregation. CBS and HFF were kindly donated from CHA Gangnam Medical Center with informed consent.

\section{Reverse transcription-polymerase chain reaction (RT-PCR)}

Total RNA was isolated using Tri-reagent (Invitrogen, Carlsbad, CA) according to the manufacturer's instructions. The concentration and quality of isolated
RNA was determined using Nanodrop 2000 spectrophotometer (Thermo fisher scientific, Rockford, IL). The purity of RNA was assessed by determining the ratio of absorbance at $260 \mathrm{~nm}$ to that at $280 \mathrm{~nm}(>1.8)$. RT-PCR was carried out using a Techne PCR system TC-100 (Bibby Scientific Ltd., UK). Total $7.5 \mu \mathrm{g}$ (1 $\mu \mathrm{g}$ /ul) RNA was reverse-transcribed using the following RT mixture: $20 \mathrm{mM} \mathrm{MgCl}_{2}$ (BioBasic Inc, Canada), $10 \times$ PCR buffer (BioBasic Inc), $10 \mathrm{mM}$ dNTPs mixture (BioBasic Inc), $0.5 \mathrm{mg} / \mathrm{ml}$ oligo (d) $\mathrm{T}^{15}$ (Bionics), $40 \mathrm{U} /$ $\mu 1$ RNase inhibitor (BioBasic Inc) and $200 \mathrm{U} / \mu \mathrm{l}$ AMV-RT (Invitrogen). RT reaction was allowed to occur for $60 \mathrm{~min}$ at $37^{\circ} \mathrm{C}$, and the resultant cDNA subjected to PCR amplification.

For the conventional PCR, cDNA were amplified using the following PCR mixture: $25 \mathrm{mM} \mathrm{MgCl}_{2}$, $10 \times \mathrm{PCR}$ buffer, $5 \mathrm{U} / \mu \mathrm{l}$ Taq polymerase, $2.5 \mathrm{mM}$ $\mathrm{dNTP}, 10 \mu \mathrm{M}$ sense and antisense primer. Amplification was performed for 35 cycles at a denaturing temperature of $94^{\circ} \mathrm{C}$ for $30 \mathrm{sec}$ and an extension temperature of $72{ }^{\circ} \mathrm{C}$ for $30 \mathrm{sec}$. Annealing temperature was set depending on the species of primer. The PCR products were mixed with $6 \times$ lading buffer $(0.25 \%$ bromophenol blue, $0.25 \%$ Xylene cyanol and $40 \%$ sucrose) and separated on 3\% agarose gels. After electrophoresis, gels were stained with ethidium bromide. DNA signals on the gels were imaged under ultraviolet light using a Bioprofile image analysis system (Vilber Lourmat, Germany). Primers used in this experiment were shown in Table 1. All PCR mixture components were purchased from Takara. HEACs cultivated with $10 \%$ FBS were named HEACs, and HEACs cultivated with $10 \%$ HS were named agg-HEACs in this study.

All reagents and chemicals were purchased from the Sigma unless otherwise designated.

\section{RESULTS}

\section{Effects of HS on HEAC}


Table 1. List of gene-specific primers for the PCR analysis

\begin{tabular}{|c|c|c|c|c|}
\hline Gene & Primer sequence & Accession number & $\begin{array}{l}\text { Size } \\
(\mathrm{bp})\end{array}$ & $\begin{array}{l}\text { Annealing } \\
\text { temperature }\end{array}$ \\
\hline GAPDH & $\begin{array}{l}\text { 5'-gaa ggt gaa ggt cgg agt c-3' } \\
\text { 5'-gaa gat ggt gat ggg att tc }-3 \text { ' }\end{array}$ & NM_002046 & 226 & 53 \\
\hline OCT4 & $\begin{array}{l}5 \text { '-cga cca tct gec get ttg ag-3' } \\
5 \text { '-cce cet gtc ccc cat tcc ta-3' }\end{array}$ & NM_203289 & 573 & 61 \\
\hline $\mathrm{SCF}$ & $\begin{array}{l}\text { 5'-cca ttg atg cct tca agg ac-3' } \\
\text { 5'-ctt cca gta taa ggc tcc aa-3' }\end{array}$ & NM_000899 & 275 & 55 \\
\hline THY1 & $\begin{array}{l}\text { 5'-gtc ctt tct ccc cca atc tc-3' } \\
\text { 5'-ggg aga cct gca aga ctg tt-3' }\end{array}$ & NM_006288 & 242 & 59 \\
\hline $\begin{array}{l}\text { Vimentin } \\
\text { (VIM) }\end{array}$ & $\begin{array}{l}5^{\prime} \text {-cct tcg tga ata cca cga cct gc-3' } \\
5^{\prime}-\text { ctg cca aga acc tgc agg agg-3' }\end{array}$ & NM_003380 & 321 & 63 \\
\hline CK18 & $\begin{array}{l}\text { 5'-gag atc gag gct ctc aag ga-3' } \\
\text { 5'-caa gct ggc ctt cag att tc-3' }\end{array}$ & NM_000224 & 357 & 57 \\
\hline GATA4 & $\begin{array}{l}\text { 5'-tcc ctc ttc cct cct caa at-3' } \\
\text { 5'-tca gcg tgt aaa ggc atc tg-3' }\end{array}$ & NM_002052 & 192 & 60 \\
\hline BMP4 & $\begin{array}{l}\text { 5'-agc cat gct agt ttg ata cc-3' } \\
\text { 5'-tca ggg atg ctg ctg agg tt-3' }\end{array}$ & NM_130851 & 384 & 55 \\
\hline HLA -ABC & $\begin{array}{l}\text { 5'-gta ttt ctt cac atc cgt gtc ccg-3' } \\
\text { 5'-gtc cgc cgc ggt cca aga gcg cag-3' }\end{array}$ & NM_001242758 & 394 & 70 \\
\hline HLA- DR & $\begin{array}{l}5^{\prime} \text {-ctg atg agc get cag gaa tca t-3' } \\
5^{\prime} \text {-gtg cat tgg cca aca tag ctg-3' }\end{array}$ & NM_019111 & 220 & 60 \\
\hline AFP & $\begin{array}{l}\text { 5'-ttt tgg gac ccg aac ttt cc-3' } \\
\text { 5'-ctc ctg gta tcc ttt agc aac tct-3' }\end{array}$ & NM_001134 & 451 & 57 \\
\hline $\begin{array}{l}\text { Brachyury } \\
\text { (T) }\end{array}$ & $\begin{array}{l}\text { 5'-gag ctc acc aat gag atg at-3' } \\
\text { 5'-ggc tca tac tta tgc aag ga-3' }\end{array}$ & NM_003181 & 335 & 57 \\
\hline NCAM1 & $\begin{array}{l}\text { 5'-gag ggg gaa gat gcc gtg at-3' } \\
\text { 5'-ata ttc tgc ctg gcc cgg atg gta g-3' }\end{array}$ & NM_181315 & 269 & 60 \\
\hline Nestin(NES) & $\begin{array}{l}5^{\prime} \text {-gcc ctg acc act cca gtt tag-3' } \\
5^{\prime} \text {-ggg agt cet gga ttt cct tcc-3' }\end{array}$ & NM_006617 & 201 & 55 \\
\hline MSX1 & $\begin{array}{l}5^{\prime} \text {-cct tcc ctt taa ccc tca cac-3' } \\
5^{\prime}-\text {-ceg att tct ctg cgc ttt tct-3' }\end{array}$ & NM_002448 & 285 & 57 \\
\hline $\begin{array}{c}\text { Slug } \\
\text { (SNAI2) }\end{array}$ & $\begin{array}{l}\text { 5'-acc tcc tcc aag gac cac agt g-3' } \\
\text { 5'-cag tgt gct aca cag cag cca ga-3' }\end{array}$ & NM_003068 & 527 & 59 \\
\hline $\mathrm{GalC}$ & $\begin{array}{l}\text { 5'-act tcc aca atc gca tgg aa-3' } \\
5 \text { '-aac ttg gcg tag cgt gaa gtg-3' }\end{array}$ & NM_000153 & 696 & 55 \\
\hline CNPase & $\begin{array}{l}\text { 5'-aag atg tca tcc tca ggg gc-3' } \\
5^{\prime} \text {-gcg gca gga agt cet tct cca g-3' }\end{array}$ & NM_033133 & 505 & 59 \\
\hline $\begin{array}{c}\beta \text {-tubulin III } \\
\text { (TUBB3) }\end{array}$ & $\begin{array}{l}\text { 5'-gcc aag ttc tgg gaa gtc at-3' } \\
\text { 5'-ggc ctg aag aga tgt cca aa-3' }\end{array}$ & NM_006086 & 209 & 57 \\
\hline MAP2 & $\begin{array}{l}\text { 5'-gaa gac tcg cat ccg aat gg-3' } \\
\text { 5'-cgc agg ata gga gga aga gac t-3' }\end{array}$ & NM_004759 & 527 & 59 \\
\hline
\end{tabular}


Table 1. Continued

\begin{tabular}{|c|c|c|c|c|}
\hline Gene & Primer sequence & Accession number & $\begin{array}{l}\text { Size } \\
\text { (bp) }\end{array}$ & $\begin{array}{l}\text { Annealing } \\
\text { temperature }\end{array}$ \\
\hline SOX9 & $\begin{array}{l}\text { 5'-gaa cgc aca tca aga cgg ag-3' } \\
5 \text { '-tct cgt tga ttt cgc tgc tc-3' }\end{array}$ & NM_000346 & 631 & 57 \\
\hline $\begin{array}{l}\text { Synaptophysin } \\
\text { (SYP) }\end{array}$ & $\begin{array}{l}5^{\prime} \text {-ttc tgc ctc get taa agc ct-3' } \\
5^{\prime} \text {-atc tgt ctg agc cet gcc-3' }\end{array}$ & NM_003179 & 537 & 63 \\
\hline NEFM & $\begin{array}{l}\text { 5'-tgg gaa atg gct cgt cat tt-3' } \\
\text { 5'-aat tgg gcg ttt cca tga ag-3' }\end{array}$ & NM_005382 & 333 & 55 \\
\hline GFAP & $\begin{array}{l}\text { 5'-ctg gag gtt gag agg gac aat ct-3' } \\
\text { 5'-tac tgc gtg cgg atc tct ttc-3' }\end{array}$ & NM_002055 & 317 & 57 \\
\hline $\begin{array}{l}\text { Fibronectin } \\
\text { (FN1) }\end{array}$ & $\begin{array}{l}5^{\prime} \text {-agc tca tca gca tcc agc ag-3' } \\
5^{\prime} \text {-act gtg get cat ctc cet cc }-3 \text { ' }\end{array}$ & NM_000638 & 255 & 60 \\
\hline $\begin{array}{l}\text { Vitronectin } \\
\text { (VTN) }\end{array}$ & $\begin{array}{l}\text { 5'-caa ggc ctg aga ccc ttc at-3' } \\
5 \text { '- tat ttc ggg ggt aat cag gg-3' }\end{array}$ & NM_000638 & 318 & 58 \\
\hline $\begin{array}{c}\text { Heatshock } 70 \\
\text { (HSPA1A) }\end{array}$ & $\begin{array}{l}5^{\prime} \text {-ttc gac gtg tcc atc ctg ac-3' } \\
5^{\prime} \text {-atg ccc tca aac agg gag tc-3' }\end{array}$ & NM_005345 & 260 & 59 \\
\hline $\begin{array}{l}\text { Heatshock } 27 \\
\text { (HSPB1) }\end{array}$ & $\begin{array}{l}\text { 5'-ctg gat gtc aac cac ttc gc-3' } \\
\text { 5'-ttt act tgg cgg cag tct ca-3' }\end{array}$ & NM_001540 & 327 & 58 \\
\hline $\begin{array}{l}\text { Heatshock } 60 \\
\text { (HSPD1) }\end{array}$ & $\begin{array}{l}5^{\prime} \text {-cca ggg tac tgg ctc ctc at-3' } \\
5^{\prime} \text {-ctt ctc gaa gcc ttc ctt gg-3' }\end{array}$ & NM_199440 & 349 & 60 \\
\hline $\begin{array}{l}\text { Heatshock } 90 \\
\text { (HSP90AB1) }\end{array}$ & $\begin{array}{l}\text { 5'-tga gga gga tga cag cgg ta-3' } \\
\text { 5'-caa aaa ggt caa agg gag cc-3' }\end{array}$ & NM_007355 & 266 & 58 \\
\hline $\begin{array}{l}\text { Nuclear protein1 } \\
\text { (Nupr1) }\end{array}$ & $\begin{array}{l}\text { 5'-tcg cac caa gag aga agc tg-3' } \\
\text { 5'-ata agt cct agg ggt ggg gg-3' }\end{array}$ & NM_012385 & 244 & 60 \\
\hline $\begin{array}{l}\text { Actinin } \\
(\mathrm{ACTN} 1)\end{array}$ & $\begin{array}{l}\text { 5'-cag aag cga agg gaa get ct-3' } \\
\text { 5'-cgc cat att gac gtg gta gg-3' }\end{array}$ & NM_001130005 & 291 & 57 \\
\hline $\begin{array}{l}\text { Cortactin } \\
(\mathrm{CTTN})\end{array}$ & $\begin{array}{l}\text { 5'-aaa gtg gat aag agc gec gt-3' } \\
5 \text { '-gcc tgt cet cct gct ctt tc-3' }\end{array}$ & NM_138565 & 376 & 59 \\
\hline $\begin{array}{l}\text { Palladin } \\
\text { (PALLD) }\end{array}$ & $\begin{array}{l}\text { 5'-tgc ctg att ctc ttc aac gc-3' } \\
5 \text { '-aag agc acc tca gac acc cc-3, }\end{array}$ & NM_014431 & 302 & 59 \\
\hline $\begin{array}{l}\text { Synaptopodin } \\
\text { (SYNPO) }\end{array}$ & $\begin{array}{l}\text { 5'-gag aag cta cgc tca tcc cc-3' } \\
5 \text { '-cct tct ccc caa aat gtc gt-3' }\end{array}$ & NM_001166209 & 291 & 59 \\
\hline $\begin{array}{l}\text { Ezrin } \\
(\mathrm{EZR})\end{array}$ & $\begin{array}{l}\text { 5'-aca agt aca aga cgc tgc gg-3' } \\
5 \text { '-act ggg gaa aac aaa cca gg-3' }\end{array}$ & NM_003379 & 259 & 58 \\
\hline Gelsolin (GSN) & $\begin{array}{l}\text { 5'-cct aag get ggt gca ctg aa-3' } \\
\text { 5'-ctt gtt gga gca ggc aaa ga-3' }\end{array}$ & NM-001258029 & 279 & 58 \\
\hline Transgelin (TAGLN) & $\begin{array}{l}\text { 5'-aag cat gtc att ggc ctt ca-3' } \\
5 \text { '-agt aga ggt gat ggg ggc ag-3' }\end{array}$ & NM_001001522 & 339 & 58 \\
\hline Caldesmon (CALD1) & $\begin{array}{l}5^{\prime} \text {-aag ggc ggt ctg gag ttt ta-3' } \\
5^{\prime} \text {-tcg cat ctc ctc cet ctt tt-3' }\end{array}$ & NM_033157 & 333 & 57 \\
\hline
\end{tabular}


A

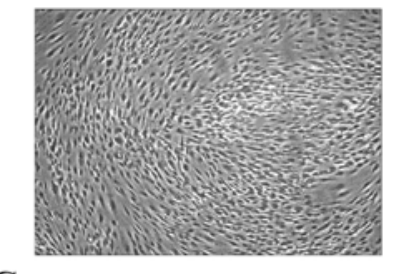

C

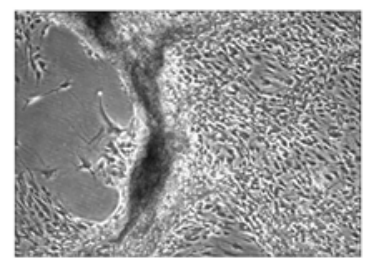

B

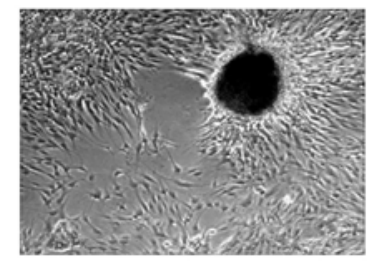

D

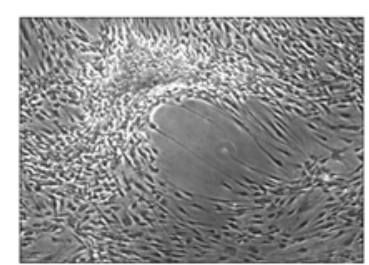

Fig. 1. Effect of HS on the mophology of HEACs during culture. A, HEACs were cultivated with $10 \%$ FBS for 11 days. B, C, D, Morphology of HEACs cultivated with $10 \%$ HS for 11 days. Various shapes of HSinduced aggregates of HEACs. $\times 40$.

HEACs were isolated and proliferated in DMEM-LG supplemented with $10 \%$ FBS until passage 3. At passage 4, HEACs were transferred to a medium containing $10 \%$ HS in a 12-well dish for 3 weeks without subculture even though they reached $100 \%$ confluence. In FBS-containing medium, HEACs did not show any morphological change even after culture for 11 days (Fig. 1A). However, as shown in Fig. 1B, C, D, when they were cultivated in $10 \%$ HS-containing medium, HEACs exhibited a movement which directed to several spots after 11 days of culture. During further culture, migrated cells began to aggregate to form several mass which looked like egg-shape (Fig. 1B), C-shape (Fig. 1C) or simple cell clump-shape (Fig. 1D).

To examine whether all cells have the same response to HS different donor cells and other medium were tested. Aggregation was not observed in $10 \%$ FBS or $0.4 \%$ BSA-containing medium. However, $10 \% \mathrm{HS}$, and $5 \%$ HS plus $5 \%$ FBS induced aggregations of HEACs after 9 days of culture for $\mathrm{HS}$ and 12 days for 5\% HS plus 5\% FBS (Fig. 2). As early as 9 days following treatment, HEACs started moving to several-specific

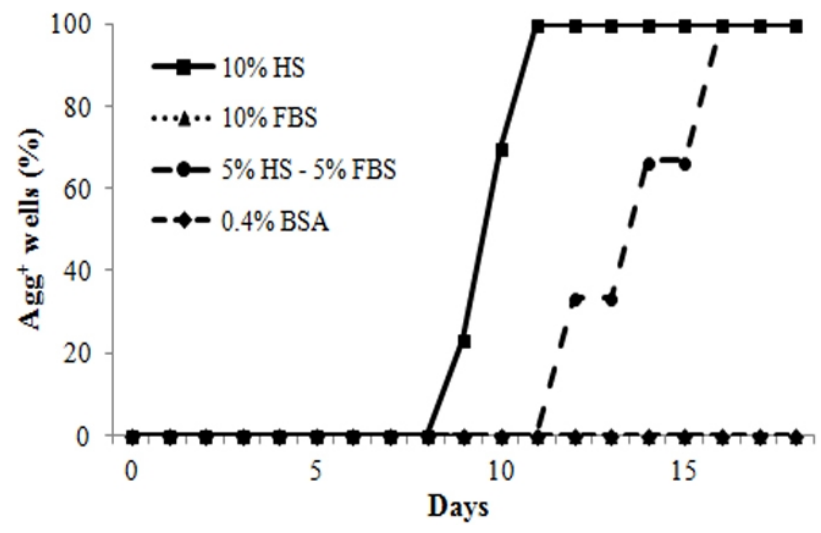

Fig. 2. Chemotactic aggregation of HEACs during culture in different conditions. HEACs were cultivated in DMEM-LG containing $10 \% \mathrm{HS}, 10 \% \mathrm{FBS}, 5 \%$ HS plus $5 \%$ FBS, or 0.4 BSA.

spots and formed aggregations. Between 9 and 11 days aggregates were observed responded to HS. In the other hands, less HS plus FBS-containing medium also induced aggregation, but starting date was delayed from 9-day to 12-day. These results are showing that HS might act as activator and FBS might act as an inhibitor.

\section{Conditions for aggregation}

To examine if there is any relationship between cell density and the treatment period, and aggregation of HEACs, cells were seeded at varying densities of $10^{2}$, $10^{3}, 10^{4}$ or $10^{5}$ cells per well of a 12 -well dish. As shown in Fig. 3A, aggregation started after culture for $16.0 \pm 1.6$ days in $10^{2} /$ well, $12.3 \pm 1.3$ days in $10^{3} /$ well, 10.0 \pm 0.4 days in $10^{3} /$ well, and $9.0 \pm 0.4$ days in $10^{5} /$ well. The results show that as the number of seeded cells increase, the aggregation form sooner $(p<0.05)$. To see the exact number of cells at the time of aggregation, cells were harvested from each group on the day the aggregation started and each cell number was counted. When initial cell density was $10^{3}, 10^{4}$ or $10^{5}$, their total cell numbers at the time of aggregation were $24.0 \pm 1.8$, $24.3 \pm 1.2$ and $29.3 \pm 2.8 \times 10^{4}$, respectively (Fig. 3B). 
$\mathbf{A}$

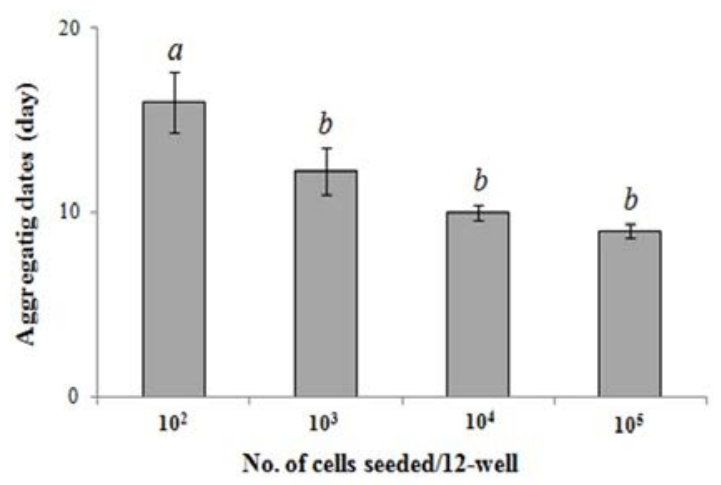

B

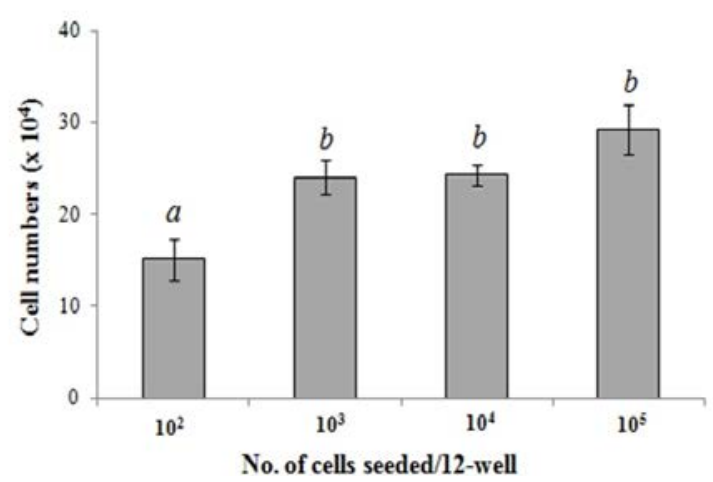

Fig. 3. Chemotactic aggregation in relation to cell number. A, The culture period required for the aggregation of $\mathrm{HE}$ ACs seeded at different cell densities. B, Total cell numbers at the time of aggregation of HEACs seeded at different cell densities. a is significantly different from b, $p<0.05$.

There was no significant difference among these conditions. However, when the initial cell density was $10^{2} /$ well, then the total cell number was $15.1 \pm 0.2 \times 10^{4}$, which was significantly smaller to the other group $(p<0.05)$. These results show that HEACs cultivated for 9 days at a density of $15.1 \times 10^{4}$ cells.

\section{Human body fluid-specific aggregation}

To investigate whether the aggregation is human body fluid-specific phenomenon, $10 \%$ of CBS, BS, FBS or $15 \% \mathrm{HFF}$ were tested. Cells were seeded at density

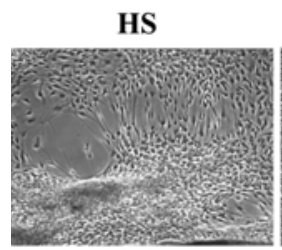

BS

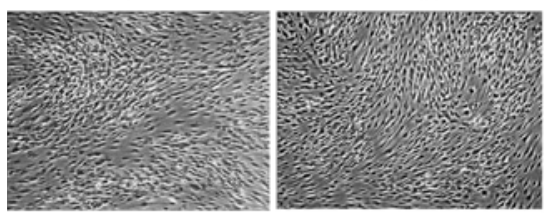

Fig. 4. Effect of various body fluids on the chemotactic aggregation of HEACs. There was neither detectable cell movement nor cell aggregate after 7 days of culture in any conditions. However, distinct aggregation was observed in HEACs cultivated for 18 days in HS-, CBS-, HFF-containing media. No behavioral change was seen in HEACs cultivated in BS- or FBS-containing medium. All supplements were added as $10 \%$ concentration except HFF which was used at $15 \%$. $\times 40$.

of $3.5 \times 10^{3} \mathrm{cells} / \mathrm{cm}^{2}$ and treated for 18 days. When cells were cultivated with medium containing $10 \% \mathrm{HS}$ and CBS or $15 \% \mathrm{HFF}$, cells began to move into several spots and aggregated, but not in $10 \%$ FBS or

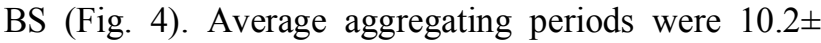
0.1 days in HS-containing medium, $13.2 \pm 0.6$ days in CBS-containing medium and $16.4 \pm 0.8$ days in HFFcontaining medium. These results indicate that chemotactic aggregation of HEACs could be induced not only by HS but also by CBS or HFF.

\section{Gene expression of HEACs, cultivated in HS-} containing medium

To investigate the effect of aggregation phenomenon on the characteristics of HEACS, expression of genes related with stem cells, stress, and cytoskeleton was examined. Agg-HEACs induced with $10 \%$ HS were examined their gene expression and it was compared with HEACs cultivated with $10 \%$ FBS. It was shown that agg-HEACs express consistently stem cell-related genes of OCT4, SCF and THY1, mesoderm/endoderm- 

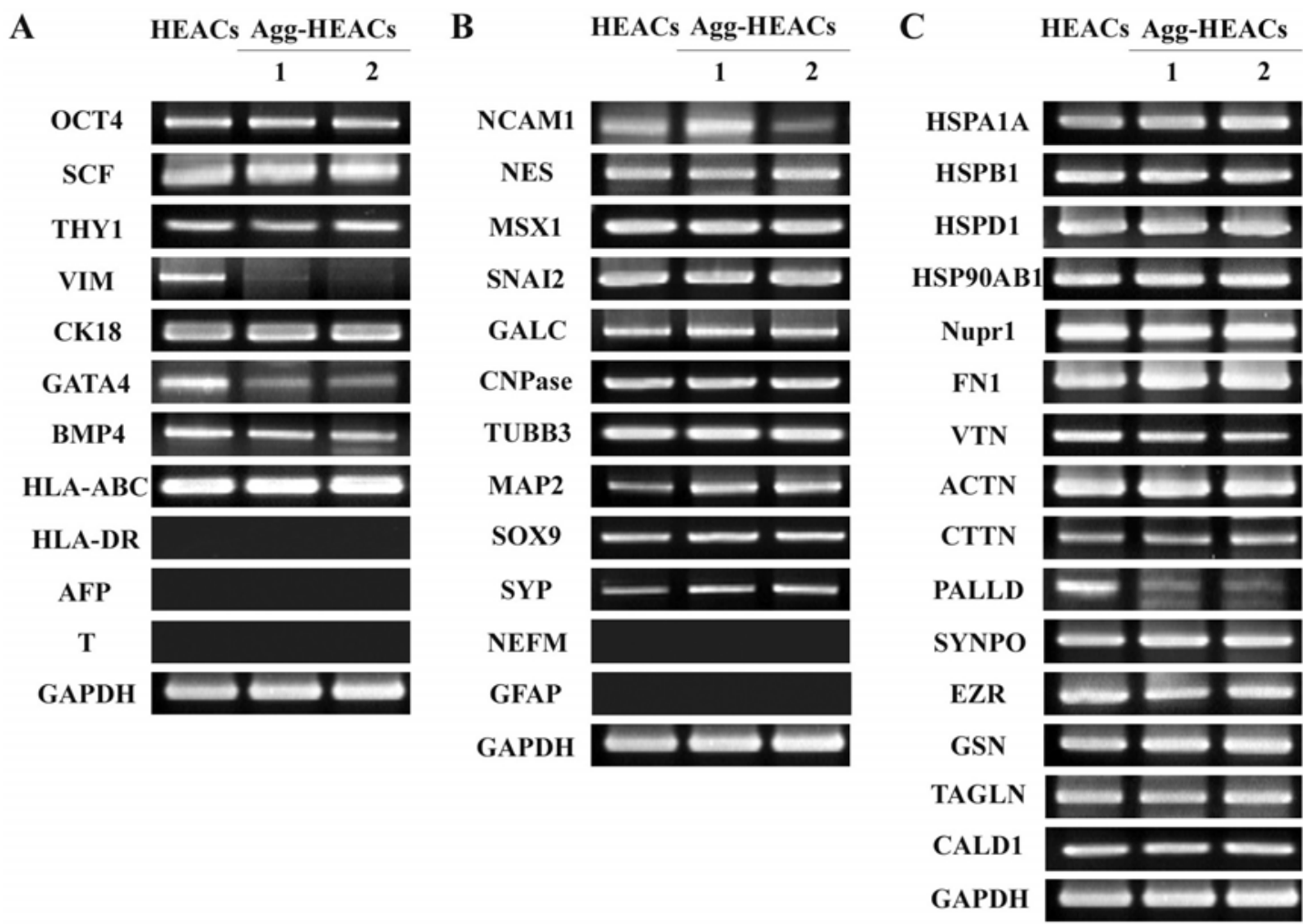

Fig. 5. Gene expression profile of HEACs during culture in HS- containing medium (A) Expression of stem cell-related genes (A), neuronal cell-related genes (B) ECM-, stress-, and cytoskeleton-related genes (C) of HEACs cultivated with 10\% FBS (HEACs) and 10\% HS (agg- HEACs) are observed using the RT-PCR. Numbers represent cell replicates.

related genes of $C K 18$, endoderm-related genes of BMP4 (Fig. 5A) but not express endoderm-specific $A F P$ and mesoderm-specific Brachyury (T). Immunerelated gene of $H L A-A B C$ was expressed in aggHEACs but not $H L A-D R$. There was no difference in expression level between HEACs and agg-HEACs. However, interestingly, agg-HEACs did not express VIM, and showed lower expression level of GATA4 gene compared to HEACs cultivated in FBS-containing medium. Previously, we reported that HEACs have neural-crest properties (Kang et al., 2009), therefore in this study we confirmed the expression of neural crest-related genes at both HEACs and agg-HEACs. The results showed that both HEACs and agg-HEACs express ectoderm- or neural progenitor-related genes of NCAM1 and NES, neural crest-related genes of MSX1,
SNAI2, and glial cell-related genes of GALC and CNPase, neuron-related genes of TUBB3 and SOX9, but they do not express both GFAP and NEFM genes, related with glial and neuron cells, respectively (Fig. 5B). However, it was found that HS-induced aggregated HEACs increase mRNA expression of neuronrelated genes of $M A P 2$ and $S Y P$. On the other hands, to examine whether aggregation phenomenon involve the cellular stress, we investigated the expression of stress-related genes. The results showed that the expression of stress-related genes of HSPA1A, HSPB1, HSPD1, HSP90AB1 and Nuprlof agg-HEACs does not changed when it compared with HEACs cultivated with 10\% FBS (Fig. 5C). Finally, to define the expression of ECM- and actin-related genes on agg-HEACs, mRNA expression was investigated. It was observed 
that both HEACs and agg-HEACs express ECM-related genes of FN1 and $V T N$ and actin-related genes of ACTN, CTTN, SYNPO, EZR, GSN, TAGLN, and CA$L D 1$ with no significant difference in expression levels while the expression of actin-related gene of PALLD was markedly decreased in agg-HEACs.

\section{DISCUSSION}

In this study we found that HEACs move and form the aggregate by the treatment of HS in vitro and the aggregation of HEACs is specifically induced by the human body fluids.

Many researchers have extensively studied the HS as FBS-substitute for expansion of MSCs. For example, it is reported that autoHS shows similar effect with FBS on characteristics of MSCs including both expansion and multi-differentiation potential into adipocyte and osteoblast (Stute et al., 2004). Some reports showed that autoHS is better than FBS in proliferation capacity of BM-MSCs (Shahdadfar et al., 2005). These results suggest that autoHS might be a suitable candidate for cultivation of MSCs. However, it is practically difficult to apply for cell therapy since a large amount of autoHS should be obtained from a single donor for cultivation of cells for transplantation. Therefore, it has been suggested that alloHS can be alternatively used for cultivation of MSCs as a feasible supplement of FBS because it can be easily obtained (Le Blanc et al., 2007; Kocaoemer et al., 2007). However, there has been a lot of controversy about alloHS for cultivation of MSCs. It has been shown that MSCs including umbilical cord-derived stem cells (UCSCs) have high proliferative potential in presence of alloHS. It showed that alloHS support a homogenous morphology and a stable expression of stem cells-related genes during long-term expansion (Hatlapatka et al., 2011). On the other hands, it has been reported that cells cultivated with alloHS enter senescence earlier than cells cultured in presence of FBS although it shows a much higher cumulative population doubling numbers until passage 6 (Kocaoemer et al., 2007). Also, some researchers argued that commercial alloHS can lead poor cellular yields, a notable cell death and morphological deterioration (Spees et al., 2004).

CBS, another human body fluid, can be used for FBSsubstitute for cultivation of MSCs as a safe and unique humanized culture condition. It has been reported that CBS support to enhanced self-renewal capacity and osteogenic potential of MSCs (Jung et al., 2009). Interestingly, it showed that MSCs cultured with CBS was detached from the flask at passage 3 , although cells showed high replicative ability until passage 2, whereas cells cultured in presence of FBS were continued to grow up as a monolayer (Shetty et al., 2007). This report supports our aggregation phenomenon of HEACs which move and form the cell aggregation in culture medium containing 10\% CBS. Follicular fluid (FF) is a liquid that surrounds the oocyte with the attached follicular cells. It is well known that FF contains various biological active proteins that affect follicular growth and maturation (Sun et al., 2011). Recently, it is reported that the FF promote the proliferation of goat umbilical cord-derived MSCs (UCMSCs). On the other hands, higher concentration of follicular fluid (10\%) showed the induction of UCMSCs into oocyte-like cells.

In this study, we observed that HEACs form aggregates in vitro by the cultivation of human body fluids including alloHS, CBS, and HFF. Until now, there are not any reports about the aggregates formation of MSCs by allogeneic HS, CBS and HFF. They could not be observed this phenomenon because subculture of cells is usually performed before cells reach the confluence on the flask. In this study, we found that HEACs form the aggregation after the confluence by alloHS, CBS, and HFF but not by FBS and BS. It showed that it takes 4-5 days to aggregate after 
confluence in culture medium containing $10 \%$ alloHS and at least 9 days from initial cultivation at seeding density of $2.6 \times 10^{4}$ cells $/ \mathrm{cm}^{2}$. When HEACs are cultivated with CBS or HFF, the culture period for the formation of aggregate of HEACs increased than alloHS. From these results, we suggest that human follicular fluid including HS, CBS and HFF have a special factor to induce the aggregation of cells. Since the aggregation was not induced by FBS and BS, further studies should be performed to investigate whether this phenomenon is only observed with human body fluids. It can be disclosed using other animal fluids such as mouse and rabbit. Furthermore, it needed to be examined whether the aggregates formation of cells is only occurred at human stem cells or not.

To investigate the effect of aggregation phenomenon on the characteristics of HEACS, expression of genes related with stem cells, stress, and cytoskeleton was examined. As a result, agg-HEACs induced by alloHS showed remarkably low expression level of VIM gene, stem cell-related marker gene. Vimentin is a type III intermediate filament (IF) and it is known as a major cytoskeletal component of mesenchymal cells (Chang $\&$ Goldman, 2004). In addition, the results showed that expression of MAP2 and SYP, neural crest-related genes, increase on agg-HEACs compared to HEACs. MAP2 serves to stabilize microtubules (MT) growth by crosslinking MT with intermediate filaments and other MT. It is known that the increase of MAP2 is observed at the neuron which exhibiting a rapid neurite extension (Bogoch \& Linial, 2007). These results are consistent with the findings of down-regulated expression of PALLD gene, a component of actin-containing microfilaments. In recent study, it has been found that downregulation of palladin by small hairpin RNA (shRNA) enhances invasive migration, indicating that the lower expression of palladin helps the cell migration (Chin \& Toker, 2010). As the internal cytoskeleton of eukaryotic cells is composed of actin mi- crofilaments, microtubules, and intermediate filaments, our results revealed that all three components of internal cytoskeleton are changed by the aggregation of cells. Taken together, our study demonstrates that aggHEACs form with the change of expression of various cytoskeleton-related genes.

It is known that various environments such as temperature shock, oxygen shock, nutrient deprivation, and confluence cause the stress to the cells (Richter et al., 2010; Majmundar et al., 2010; Sengupta et al., 2010). To examine whether an aggregation structure can be an external factor of the stress, expression of stress-related genes including HSPA1A, HSPB1, HSPD1, HSP90AB1 and Nuprl were examined in agg-HEACs. As shown in Fig. 5C, there were no differences of gene expression in both HEACs and agg-HEACs. This result suggests that stress might not be influenced when HEACs were cultivated with $10 \%$ HS. These are consistent with previous reports that demonstrated a stable phenotype of MSCs without the cell density (Haack-Sørensen et al., 2012).

In summary, these results demonstrated the movements and aggregation of HEACs by human body fluids, including HS, CBS and HFF at the first time. And it revealed that the expression of cytoskeletonrelated genes is changed by cultivating with HS.

\section{ACKNOWLEDGEMENT}

This work was supported by a research grant from Seoul Women's University (2011).

\section{REFERENCES}

Assmus B, Schachinger V, Teupe C, Britten M, Lehmann R, Dobert N, Grunwald F, Aicher A, Urbich C, Martin H, Hoelzer D, Dimmeler S, Zeiher AM (2002) Transplantation of progenitor cells and regereration enhancement in acutemycardial infarc- 
tion. Circulation 106:3009-3017.

Bieback K, Hecker A, Kocaömer A, Lannert H, Schallmoser K, Strunk D, Klüter H (2009) Human alternatives to fetal bovine serum for the expansion of mesenchymal stromal cells from bone marrow. Stem Cells 27:2331-2341.

Bogoch Y, Linial M (2007) Coordinated expression of cytoskeleton regulating genes in the accelerated neurite outgrowth of P19 embryonic carcinoma cells. Exp Cell Res 314:677-690.

Burridge PW, Thompson S, Millrod MA, Weinberg S, Yuan X, Peters A, Mahairaki V, Koliatsos VE, Tung L, Zambidis ET (2011) A universal system for highly efficient cardiac differentiation of human induced pluripotent stem cells that eliminates interline variability. PLoS One 6:e18293.

Chang L, Goldman RD (2004) Intermediate filaments mediate cytoskeletal crosstalk. Nat Rev Mol Cell Biol 5:601-613.

Chin YR, Toker A (2010) The actin-bunding protein palladin is an Akt1-specific substrate that regulates breast cancer cell migration. Mol Cell 38:333-344.

D'Amour KA, Bang AG, Eliazer S, Kelly OG, Aqulnick AD, Smart NG, Moorman MA, Kroon E, Carpenter MK, Baetge EE (2006) Production of pancreatic hormone-expressing endocrine cells from human embryonic stem cells. Nat Biotechnol 24: 1392-1401.

Erickson GA, Bolin SR, Landgraf JG (1991) Viral contamination of fetal bovine serum used for tissue culture: risks and concerns. Dev Biol Stand 75: 173-175.

Haack-Sørensen M, Hansen SK, Hansen L, Gaster M, Hyttel P, Ekblond A, Kastrup J (2012) Mesenchymal stromal cell phenotype is not influenced by confluence during culture expansion. Stem Cell Rev May 30. [Epub ahead of print]

Hatlapatka T, Moretti P, Lavrentieva A, Hass R, Marquardt N, Jacobs R, Kasper C (2011) Optimi- zation of culture conditions for the expansion of umbilical cord-derived mesenchymal stem or stromal cell-like cells using xeno-free culture conditions. Tissue Eng Part C Methods 17:485-493.

Horwitz EM, Prockop DJ, Fitzpatrick LA, Koo WW, Gordon PL, Neel M, Sussman M, Orchard P, Marx JC, Pyeritz RE, Brenner MK (1999) Transplantability and therapeutic effects of bone marrow-derived mesenchymal cells in children with osteogenesis imperfecta. Nat Med 5:309-313.

Jung J, Moon N, Ahn JY, Oh EJ, Kim M, Cho CS, Shin JC, Oh IH (2009) Mesenchymal stromal cells expanded in human allogenic cord blood serum display higher self-renewal and enhanced osteogenic potential. Stem Cells Dev 18:559-571.

Kang HM, Kim J, Park S, Kim J, Kim H, Kim KS, Kim EJ, Seo SI, Kang SG, Lee JE, Lim H (2009) Insulin-secreting cells from human eyelid-derived stem cells alleviate type I diabetes in immunocompetent mice. Stem Cells 27:1999-2008.

Kaufman DS, Hanson ET, Lewis RL, Auerbach R, Thomason JA (2001) Hematopoietic colony-forming cells derived from human embryonic stem cells. Proc Natl Acad Sci USA 98:10716-10721.

Kocaoemer A, Kern S, Klüter H, Bieback K (2007) Human $\mathrm{AB}$ serum and thrombin-activated plateletrich plasma are suitable alternatives to fetal calf serum for the expansion of mesenchymal stem cells from adipose tissue. Stem Cells 25:1270-1278.

Kroon E, Martinson LA, Kadoya K, Bang AG, Kelly OG, Eliazer S, Young H, Richardson M, Smart NG, Cunningham J, Agulnick AD, D'Amour KA, Carpenter MK, Baetge EE (2008) Pancreatic endoderm derived from human embryonic stem cells generates glucose-responsive insulin-secreting cells in vivo. Nat Biotechnol 26:443-452.

Le Blanc K, Samuelsson H, Lönnies L, Sundin M, Ringdén O (2007) Generation of immunosuppressive mesenchymal stem cells in allogeneic human 
serum. Transplantation 84:1055-1059.

Ma HY, Yao L, Yu YQ, Li L, Ma L, Wei WJ, Lu XM, Du LL, Jin YN (2012) An effective and safe supplement for stem cells expansion ex vivo: cord blood serum. Cell Transplant 21:857-869.

Majmundar AJ, Wong WJ, Simon CM (2010) Hypoxia inducible factors and the response to hypoxic stress. Mol Cell 40:294-309.

Minguell JJ, Erices A, Conget P (2001) Mesenchymal stem cells. Exp Biol Med 226:507-520.

Moriguchi H, Chung RT, Sato C (2010) Tumorigenicity of human induced pluripotent stem cells depends on the balance of gene expression between p21 and p53. Hepatology 51:1088-1089.

Pittenger MF, Mackay AM, Beck SC, Jaiswal RK, Douglas R, Mosca JD, Moorman MA, Simonetti DW, Craig S, Marshak DR (1999) Multilineage potential of adult human mesenchymal stem cells. Science 284:143-147.

Prockop DJ (1997) Marrow stromal cells as stem cells for nonhematopoietic tissues. Science 276:71-74.

Qiu P, Bai Y, Liu C, He X, Cao H, Li M, Zhu H, Hua J (2012) A dose-dependent function of follicular fluid on the proliferation and differentiation of umbilical cord mesenchymal stem cells (MSCs) of goat. Histochem Cell Biol 138:593-603.

Reubinoff BE, Pera MF, Fong CY, Trounson A, Bongso A (2000) Embryonic stem cell lines from human blastocysts : Somatic differentiation in vitro. Nat Biotechnol 18:399-404.

Richter K, Haslbeck M, Buchner J (2010) Life on the verge of death: the heat shock response revisited. Mol Cell 40:253-266.

Sengupta S, Peterson TR, Sabatini DM (2010) Regulation of the mTOR complex 1 pathway by nutrients, growth factors, and stress. Mol Cell 40: 310-322.

Shahdadfar A, Frønsdal K, Haug T, Reinholt FP, Brinchmann JE (2005) In vitro expansion of human mesenchymal stem cells: choice of serum is a determinant of cell proliferation, differentiation, gene expression, and transcriptome stability. Stem Cells 23:1357-1366.

Shetty P, Bharucha K, Tanavde V (2007) Human umbilical cord blood serum can replace fetal bovine serum in the culture of mesenchymal stem cells. Cell Biol Int 31:293-298.

Spees JL, Gregory CA, Singh H, Tucker HA, Peister A, Luych PJ, Hsu SC, Smith J, Prockop DJ (2004) Internalized antigens must be removed to prepare hypoimmunogenic mesenchymal stem cells for cells and gene therapy. Mol Ther 9:747-756.

Stute N, Holtz K, Bubenheim M, Lange C, Blake F, Zander AR (2004) Autologous serum for isolation and expansion of human mesenchymal stem cells for clinical use. Exp Hematol 32:1212-1225.

Sullivan GJ, Hay DC, Park IH, Fletcher J, Hannoun Z, Payne CM, Dalgetty D, Black JR, Ross JA, Samuel K, Wang G, Daley GQ, Lee JH, Church GM, Forbes JS, Iredale JP, Wilmut I (2010) Generation of functional human hepatic endoderm from human induced pluripotent stem cells. Hepatology 51:329335.

Sun YL, Ping ZG, Li CJ, Sun YF, Yi KL, Chen L, Li XY, Wang XL, Zhou X (2011) Comparative proteomic analysis of follicular fluids from normal and cystic follicles in sows. Reprod Domest Anim 46: 889-895.

Takahashi K, Tanabe K, Ohnuki M, Narita M, Ichisaka T, Tomoda K, Yamanaka S (2007) Induction of pluripotent stem cells from adult human fibroblasts by defined factors. Cell 131:861-872.

Tateishi K, Ando W, Higuchi C, Hart DA, Hashimoto J, Nakata K, Yoshikawa H, Nakamura N (2008) Comparison of human serum with fetal bovine serum for expansion and differentiation of human synovial MSC: potential feasibility for clinical applications. Cell Transplantat 17:549-557. 
Tekkatte C, Vidyasekar P, Kapadia NK, Verma RS (2012) Enhancement of adipogenic and osteogenic differentiation of human bone-marrow-derived mesenchymal stem cells by supplementation with umbilical cord blood serum. Cell Tissue Res 347: 383-395.

Thomson SR, Wishart TM, Patani R, Chandran S, Gillingwater TH (2012) Using induced pluripotent stem cell (iPSC) to model human neuromuscular connectivity: promise or reality? J Anat 220:122130.

Wei X, Wang CY, Liu QP, Li J, Zhao FT, Lian JQ, Xie YM, Wang PZ, Bai XF, Jia ZS (2008) In vitro hepatic differentiation of mesenchymal stem cells from human fetal bone marrow. J Int Med Res 36: 721-727.

Wollert KC, Meyer GP, Lotz J, Ringes-Lichtenberg S, Lippolt P, Breidenbach C, Fichtner S, Korte T, Horning B, Messinger D, Arseniev L, Hertenstein
B, Graser A, Drexler H (2004) Intracornonary autologous bone-marrow cell transfer after myocardial infarction: the BOOST randomized controlled clinical trial. Lancet 364:141-148.

Woodbury D, Schwarz EJ, Prockop DJ, Black IB (2000) Adult rat and human bone marrow stromal cells differentiate into neurons. J Neurosci Res 61: 364-370.

Yamamoto $\mathrm{N}$, Isobe $\mathrm{M}$, Negishi A, Yoshimasu $\mathrm{H}$, Shimokawa H, Ohya K, Amagasa T, Kasugai S (2003) Effects of autologous serum on osteoblastic differentiation in human bone marrow cells. J Med Dent Sci 50:63-69.

Yamanaka S (2009) Elite and stochastic models for induced pluripotent stem cell generation. Nature 460: 49-52.

(Received 7 November 2012, Received in revised form 21 December 2012, Accepted 24 December 2012) 